\title{
Authenticity and Greek Traditional Dance: An Ethnographic Approach
}

\author{
Niki Niora \\ School of Physical Education and Sports Science \\ National and Kapodistrian University of Athens \\ 41, Ethnikis Antistaseos str., 17237 Daphne \\ Athens, Greece \\ Maria I. Koutsouba \\ School of Physical Education and Sports Science \\ National and Kapodistrian University of Athens \\ 41, Ethnikis Antistaseos str., 17237 Daphne \\ Athens, Greece \\ Vasiliki Lalioti \\ School of Philosophy, Department of Music Studies \\ National and Kapodistrian University of Athens \\ University Campus (Panepistemiopolis) Zografou Area \\ Athens, Greece \\ Vasiliki Tyrovola \\ School of Physical Education and Sports Science \\ National and Kapodistrian University of Athens \\ 41, Ethnikis Antistaseos str., 17237 Daphne \\ Athens, Greece
}

\begin{abstract}
The Greek traditional dance workshops are a folklore phenomenon, within the context of which "authentic" dance forms of local traditions are presented. The aim of this paper is to study Greek traditional dance within a long-lasting annual dance workshop that takes place in Greece under the auspice of the cultural association "En Choro". The central focus of this paper is the concept of "authenticity," and the way it is perceived by the organisers, originators, instructors, and participants. For this purpose, ethnographic research was employed in its application to the dance research. In order to analyse, elaborate, and interpret ethnographic data related to the concept of "authenticity" of the Greek traditional dance, this study provides a comparative analysis of the gathered qualitative data and informants' views. The guiding theoretical framework of this research was rooted in the prevalent views in the literature regarding folklore, folklorism, tradition, and authenticity. This study has found that, regardless of a widely accepted belief that the workshop represents the "authentic" transmission of the traditional dance, it actually represents the creation of a new "space". Within the context of this space, the "aim can't be authenticity in itself" (Liavas, 2013), since the traditional dance as an intangible product turns into a product of management, creating new dancing performances through the night festivities and the teacher-centred teachings.
\end{abstract}

Keywords: Greek traditional dance, dance ethnography, dance "authenticity", dance workshops, folklore, folklorism, tradition

\section{Introduction}

The case of the Greek traditional dance workshops can be classified as a folklore phenomenon, since it promotes revival, preservation, and dissemination of tradition through the teaching of the "authentic" dance form. Dance students, dance teachers, as well as dancers enrich their dance repertoire, relying on the common foundation of "authenticity" of the instructors and material they disseminate. This concept has been widely spread within the space of the traditional dance workshops. It offers certain moral guarantees, according to the popular belief, against the commercialisation of the dance. 
It is related to what and how elderly local dancers dance, and who could be initially observed in the setting of their villages; and, later on, in other places, such as conferences or Greek traditional dance workshops for Greek teachers and dancers, which had made their appearance at the same time. The practice of inviting local dancers to participate in the workshops during this period is directly related to the students' need to gain an "authentic" knowledge, and, at the same time, enrich their repertoire at the time when dance teachers did not have a great diversity in their dance repertoire. In addition, the certificates of completion given after each workshop enabled the establishment of the associations organising Greek traditional dance workshops as a valid source of knowledge, while also providing an important qualification for each participant's resume.

Beginning from mid-late 80s the search for the "authentic" form of traditional dance starts to gain popularity in Greece. One of the main reasons for it is the existence of fictional and stereotypical beliefs among Greeks that the purest and most authentic national values are primarily expressed through dance, music, and national costumes (Bendix, 1997a, 1997b; Felföldi, 2002; Kaschl, 2003; Morrison, 2003; Papapavlou, 2010; Shay, 2002).

Although almost thirty years have passed since then, the perception on the "original" and "authentic" dance material has not been significantly altered. From the first moment one enters the "space" of the workshop organised by the cultural company "En Choro", it becomes evident that the objective pursued by the participants is to "approach the tradition in the right way".

The main focus of this paper is to examine the case of the Greek traditional dance workshops in Greece, specifically, the workshop organised by the non-profit cultural association "En Choro". These workshops have been taking place since 1991 and continue until today (1991-2010 under the auspices of the Ethnographic Centre of Teachers of Magnesia and from 2011 until today under the auspices of a non-profit cultural association "En Choro").

\section{Aim of the study}

The goal of this paper is to examine the concept of "authenticity" with regards to the Greek traditional dances, taught within the context of the workshops organised by the cultural company "En Choro".

\section{Methodology}

The methodological framework of this paper derives from the research carried out during the Greek traditional dance workshops, organized by the cultural association "En Choro" in 2011, 2013 and 2014 under the title "Greek Traditional Dance Workshops" (Niora, 2017). This methodological framework used a combination of quantitative and qualitative research methods. More specifically, ethnographic research was carried out on the principles of participant observation as it applies to the dance research (Buckland, 1999; Giurchescu \& Torp, 1991; Koutsouba, 1991, 1997, 1999; Lange, 1980, 1984; Tyrovola, 2008; Tyrovola, Karepidis, \& Kardaris, 2007). The participants included 195 men and women (162 returning and new participants, 24 instructors presenting a dance repertoire, 6 instructors presenting special issues, 2 external informants and the head of secretarial support).

This study focuses on the concept of "authenticity" within the context of dance folklore/folklorism and tradition. Guided by the most prevailing approaches in the current literature regarding folklorism, tradition, and authenticity, this paper presents a comparative interpretation of those concepts, in juxtaposition with the interpretative versions given by the informants. Based on that, we attempt to describe the ways in which the "authenticity" of the traditional dance is being perceived, not only by use of videos (of customs, dance interpretation, local fairs, etc.), but also through the teaching by the organisers, the lecturers and the students within the context of the workshop.

\section{Dance, folklore/folklorism, tradition and "authenticity"}

The concept of the "traditional authentic dance" was an essential element of Greek national identity during the period of establishment of the Greek state, which was achieved through the use of ethnography, history, support programmes for the promotion of local culture, and cultural associations, among other things (Lalioti, 2010; Papapavlou, 2010). One of the examples if this is the cultural association "En Choro".

The concepts of tradition and folklore are inextricable, since folklore is a way of managing the tradition. These two concepts are directly related with space and time, as well as with the concept of "authenticity". The "authentic space" within the conceptual context of the folklore includes the "people living in the villages", the "pure" carriers of the "true" and "unalloyed" tradition (Papapavlou, 2010, p. 92-93). On the contrary, the term "folklore" normally refers to a negative aspect of the tradition within the perception of Nikos, who claim that "the folklore consists of those elements that got infiltrated in the longer term. ... A bunch of incoming elements. ... What I consider to be tradition is long gone. I am referring to the tradition that existed in closed rural societies". 
During the workshop, such terms as "authenticity", "folklore", "pure", "authentic", "unalloyed", "genuine" were used. According to the participants' interviews and prevailing view among the participants, the authenticity of the dances is a privilege of the local people only, from whom we can extract the true version of a traditional dance. Thus, there are two ways to learn the "authentic" form of the dance: (1) to dance with the local people, or (2) to watch dance recordings with older dancers. This is the reason why the organisers Giannis and Nikos, always demand from the instructors, as evidence of authenticity, "to carry in their baggage all the proof and evidence regarding their presentation in case anyone questions them" (see figure 1).

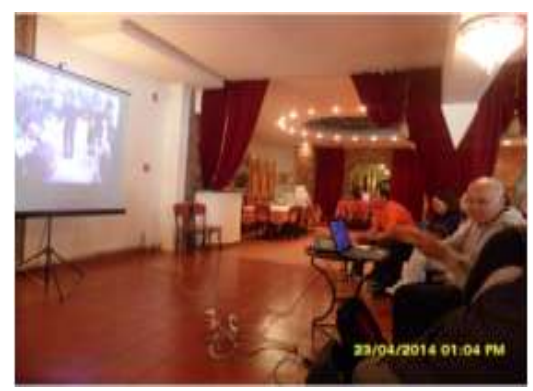

Figure 1: Prantsidis I., one of the organizers is giving geographical, ethnographic, and historical data, including information about Eastern Rumelia, while watching dance recordings from the past (2014).

The quality of the presentation of dance repertoire in each region, as well as the "authenticity" can both constitute criteria for the selection of the instructors. The view that all the workshops differ from one another in quality is reflected in the words of one of the informants: "I don't know and haven't noticed how they make the selection, but I reckon they use criteria that are related to the authenticity and the quality of the region presented. Most certainly, it is not a marketable factor, most certainly it is not the catchy one, which aims to impress the market. And this is what makes it unique [that workshop 'En Choro'] the fact that they are regions that have not been presented before or probably it is the first recording ever made and they are, therefore, launching it".

There are numerous cases of Greek traditional dance instructors, who present themselves as "authentic" dancers or "authoritative" dance teachers, having acquired knowledge of the dance repertoire from instructors in traditional dance workshops or from other teachers, even if they did not carry out any research for dance material used in their teaching. The participation of both reputable as well as less known instructors in the workshop has been the springboard to their exposure both within the workshop space and the rest of Greece. Their constant exposure led to the corruption of the "authenticity" of the dances taught within the workshops space.

In terms of authenticity, there are three categories of dance teachers: a) the first category consists of those who believe that they provide true representation of the material they teach, b) the second category includes the majority of the dance teachers, who believe that the knowledge acquired has been validated as authentic in a way that they can transmit it to their students, and c) the third category consists of the fewer in number dance teachers, who will try to cross-check the knowledge acquired from a workshop or any other means, either by participating in other workshops or seminars, or even visit the different communities in order to "watch" the dance in its original place. This opinion is expressed by Giorgos: "Yes, indeed, I believe that a few would say, "what I present is authentic, I am a true mouthpiece of what they teach'. This is a statement few would dare to say. Many would say, 'I hold a certification that what I watched is authentic, and that's it. It is what so-and-so showed, and that's all, no need for anyone else. This is what he or she showed me, this is what I show and I do hold the certification, I should ask no one else and I would show what I was shown and it is for sure authentic'. I think those are the three general categories, as I think of them now. In my view, the highest percentage is positioned in the centre".

Although the prevailing view is that an "authentic" dance is found in the village, the testimonies of the participants confirm that the students are taught an "authentic" dance form, since the instructors are experts-authorities. At the same time their experiential connection to the dance, along with their research, corroborates the validity of the content of the workshop. That perception is reflected in the words of the workshop organiser Giannis: "Yes, indeed, we tried to bring teachers that had some type of connection with the place, and had also initiated their research procedure, meaning, what they presented there had been in some way cross-checked. Certainly, there were some cases where performance was poor. When we first started [in 1991] the part of the research was not yet an issue to consider".

Due to their perseverance and dedication to the dance workshops, the organisers have acquired an extensive experience in research. By adopting and transmitting philosophy of an "authentic" form of dance, they have managed to induct many participants, especially the older ones, into that mentality. 
Thus, the older participants have acquired common codes, which allow them to instantly perceive the skills and knowledge of each instructor, since, as Fotini mentioned, that "you can tell from far away that a person does not transmit the authenticity, for we have been in the market for years".

The view that an "authentic" and "true" tradition is found only in its birthplace has been supported several times by the informants during the interviews. According to Thanasis, "the authentic lies where it is born, within the village, the local fair, when and where it will be expressed. This is what "authentic" means for me. [...] I think adds that the "authentic" dance is the one that means "we are not committing any corruption, there is no choreography involved, the modern element is inexistent, in a way that the authentic is the unalloyed, without any style fusion".

According to another informant, even though authenticity is produced within the local community, the authenticity of the local dances, however, is not influenced by its transition into the workshop space. This is the reason why Lefteris believes that "the authentic is what the local society produces. [...] Only time and space are changing. But it is authentic, if they sing and they dance, it is authentic. They might not reach the performance one would expect to see on the square or church courtyard of the village, but it is authentic indeed".

Another view is that the authentic dancer is the one who can dance spontaneously, focusing exclusively on the joy of dancing, without thinking of others, or the one who has learned to dance from elderly dancers in his or her own village. Thus, the authenticity is related to the teaching of authentic steps and movements on a part of the instructors, as well as the reproduction and execution of the same steps and movements on a part of the dancers. One of the informants, Konstantina, states: "The authenticity lies in the fact that when someone becomes the first dancer in the dance circle, he/she would dance for his/her own pleasure, meaning that he/she would not think of the audience, or its reaction, but on the contrary, he/she would dance because it is what he/she really craves for. And this is precisely what comes out [in the dance]. Truth be told, you can tell when a person gets right down to it. And, apart from that, helshe is authentic in his/her village when acquired knowledge comes from some elderly person".

Every night, participants, accompanied by a music band representing the style of each region, repeat the dance repertoire they are being taught during the classes (see figures 2 and 3). This way, they are given a chance to repeat, practice, assimilate, and enjoy dance repertoire, taught during each training day, alongside the instructor or local authentic dancers.

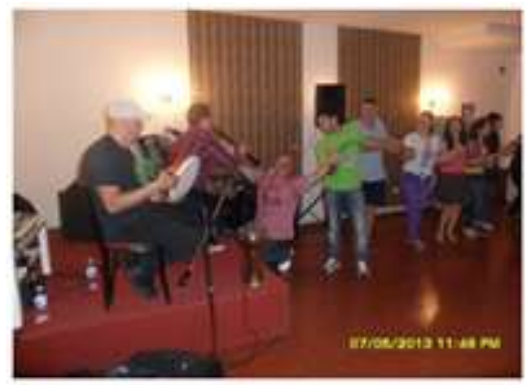

Figure 2: evening feast (2013)

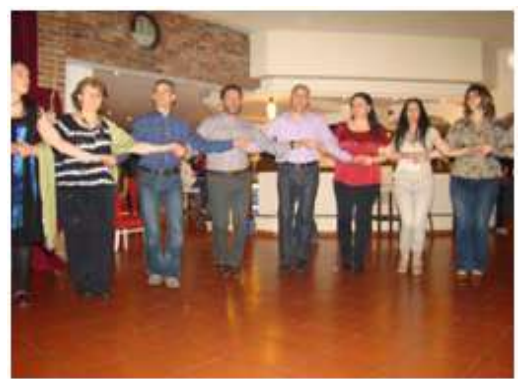

Figure 3: evening feast (2014)

For example, during the sessions of dances from Vamvakofyto (Serres, region of Macedonia) and evening festivities, local women came to participate, dressed in their traditional costumes, thus validating their authentic presence, as well as the authenticity of the dances taught. According to the instructor of Vamvakofyto, "dances till now are intact and pure".

The notion of authenticity also emerges during the evening festivities, since there is a group of older dancers, who know which tunes to request from the music band, and how each song is to be danced. According to Lefteri "when the feast has older dancers, ... well, it does possess some authenticity. That is to say, if a group of us over the age of 40 gets up to dance, there is certainly an authenticity. That authenticity exists since we ask for our own tunes, we dance in a specific way... it does have an authenticity".

At the end of each workshop, each participant is issued a certificate of participation, which validates the acquired knowledge of every participant, since dance teachers can use it to demonstrate their profound interest in teaching Greek traditional dances, and their broad spectrum of knowledge. Thus, Lefteris mentions that "it is taken into account in the personal profile [...] overall image of every interested person".

An analysis of the questionnaire, administered in 2011, has found that almost all students participate in the workshop for the following reasons: to learn the dance repertoire; for leisure purposes; to acquire experience or further knowledge; to develop their own critical thinking skills; because they are fond of traditional music and traditional music instruments. 
Furthermore, the participants were interested in acquiring ethnographic knowledge from local people, meeting and getting in contact with colleagues and dancers, having access to teaching material, exchanging opinions and achieving a better understanding of the dance. Other reasons for participating in the workshop were acquiring deeper knowledge of other geographical regions, cross-checking information to get more details, meeting people who share the same interest and love for tradition, but also the curiosity on how the workshop works, as well as viewing dancers coming from across several places in Greece. The objective of the participants did not only include getting acquainted with the Greek tradition "in the right way", but also finding out if a specific workshop evolved or diversified in comparison to the older days workshops, improving their teaching technique, exposing themselves to a combination of traditional culture and structured knowledge, but also preserving the panhellenic group, insofar as that workshop has evolved into " $a$ place of pilgrimage and a yearly meeting point for friends for over 20 years" as Dimos mentioned (see figures 4 and 5).

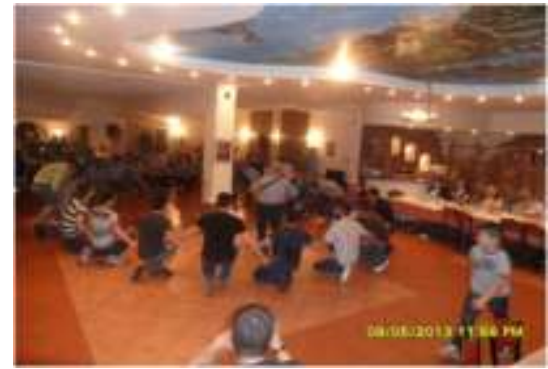

Figure 4: evening feast (2013)

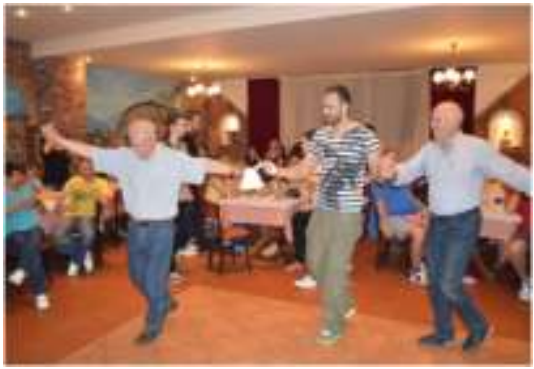

Figure 5: evening feast (2013)

During the 22nd "En Choro" workshop in 2013, 65 participants were given a questionnaire about their opinions regarding the style of the dances, the level of confidence in knowledge transmitted by the selected teachers, as well as the level of "authentic" knowledge acquired, $65 \%$ of the survey participants believed that they could dance exactly as they were taught and in the same way locals would dance it, $72 \%$ believed that they can dance as well as their codancers, and $60 \%$ believed that they can dance just as well as their teacher. Moreover, $78 \%$ of the study participants were confident that their dance reflected the style of the taught regions, whereas 55\% thought that the style of each region is perfectly reflected by the way their teachers dance. A mere $40 \%$ of the participants have confidence in the knowledge of their selected teachers and the way in which they transmit it. Furthermore, 63\% of the participants believed that information acquired by teachers provides a sufficient representation of the taught region, $48 \%$ of the participants felt like they were at the village, which symbolises the source of knowledge for them, whereas only a $19 \%$ believed they sang same way as locals did. Lastly, on average, $83 \%$ of the participants believed they acquired authentic knowledge about dance, singing, traditional costumes, musical instruments, and festivities, $94 \%$ of the participants believed they acquired authentic knowledge regarding dance, while 74\% - about singing, $82 \%$ - about musical instruments, and $91 \%$ believed they acquired authentic knowledge about evening festivities (see Table 1).

Table 1. Analysis of the participants' beliefs and opinions with regards to authenticity of dance knowledge.

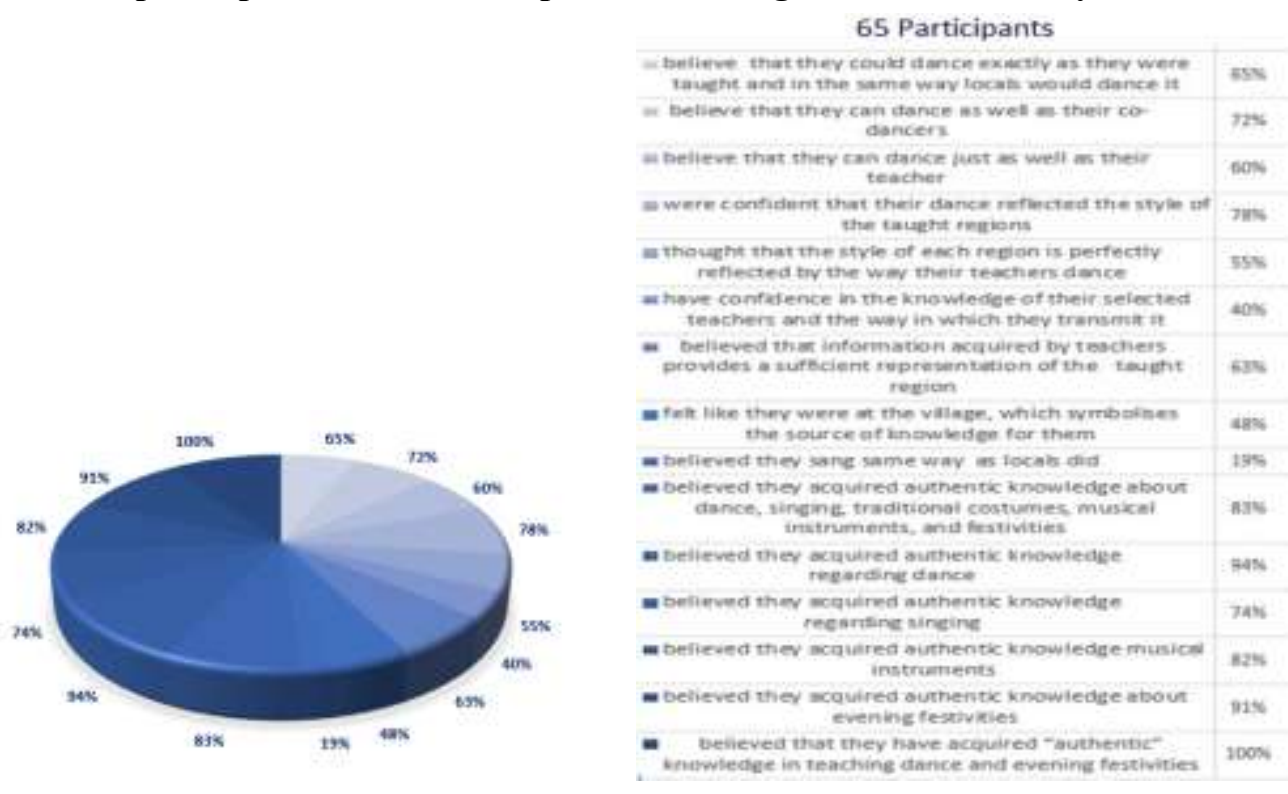


Admittedly, we have observed through this study that the place of the "authentic" and the "true" dance is in the village, and therefore, people of the village are "authentic". At the same time, almost $100 \%$ of the participants, believed that they have acquired "authentic" knowledge in teaching dance and evening festivities: actions that constitute the main transmission sources of the dance material. The conviction that "authenticity" is transmitted within the context of the workshop is based on various perceptions that are shared amongst the participants. Thus, locals are considered to be an "authentic-pure" construct of the workshops, regardless of the place where they dance. Therefore, it is believed that within the lectures of the workshop the authentic dance form is transmitted, especially when older local dancers take part in it (see figure 6).

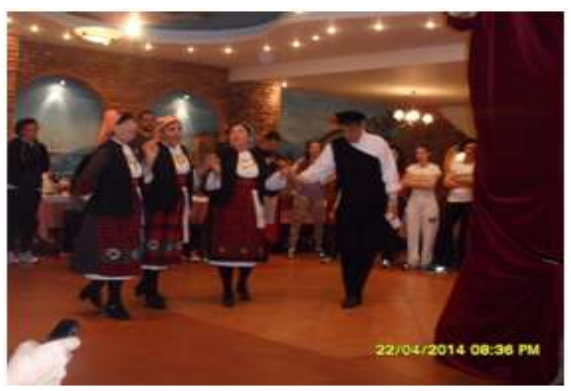

\section{Discussion}

Figure 6: Vamvakofyto (Serres, region of Macedonia) (2014)

The workshop of Greek traditional dance organised by a cultural association "En Choro" is a birthplace of cultural knowledge and, at the same time, a place of management of Greek traditional dance education. The workshop and all actions that take place within this context can be identified with the notion of tradition and folklore/folklorism. This notion has been supported by various researchers, who believed that traditional dance, as a folkloric element, is transmitted through teaching in a new environment, different than its initial context (Bendix, 1997b; Demas, 2004; Hanna, 1987; Hoerburger, 1968; Keali'inohomokou, 1972; Koutsouba, 1991, 1997, 2010a; Liavas, 2013; Meraklis, 1972; Nahachewsky, 1995, 2001; Papapavlou, 2010; Shay, 1999, 2002).

Starting from the very first workshops, the organisers as mentioned in their publications, aimed to preserve dance and music, "the elements of the traditional culture that compose the Greek identity", in order to raise awareness amongst dance teachers, who would use their teaching to prevent Greek youth from adopting any foreign elements [1]. Moreover, the search for the authentic and the assumption that the place of the "authentic" and the "pure" is the village as a place of origin of dance, as well as the fact that the "authentic dancers" are the village people that have experienced and used the dance material in their everyday life, is a widely shared view among the participants of the workshops. This is due to the fact that everybody, both fictionally and stereotypically, shares the conviction that dance, music, and costumes express the most pure and the most authentic values of a nation (Bendix, 1997a, 1997b; Felföldi, 2002; Kaschl, 2003; Morrison, 2003; Papapavlou, 2010; Shay, 2002).

Since the mid- $19^{\text {th }}$ century, the concept of resistance to corruption started gaining ground (Meraklis, 2001). Special emphasis was put on our resemblance to our ancient ancestors, and our connection with our "glorious past" (Deltsou, 2003; Kyriakidou-Nestoros, 2008; Mpada, 2011). From the beginning of the $20^{\text {th }}$ century, a new narrative is projected, without, however, fully rejecting the connection of the dances with the ancient world. A new narrative is related to the dipole tradition-authenticity, which represents authenticity against corruption, misrepresentation and exploitation of the monuments, poetry, popular dances and songs, through history, ethnography, cultural associations and programmes that are related to the popular culture (Formozis, 1932; Lalioti, 2010; Meraklis, 1972, 2004; Papapavlou, 2010; Politis, 1920). Admittedly, by the middle of the $20^{\text {th }}$ century, when dance teaching and dissemination start to gain interest, the majority of dance teachers had embraced the opinions about authenticity and originality of everything traditional. Therefore, they used the term "national", "folklore", "popular", "traditional" dance in order to denote the relation that dance maintained with antiquity (Agrafioti, 1994), and the hellenicity-Greek identity (Antzaka-Vei \& Loutzaki, 1999; Filippou, 1999; Koutsouba, 2012).

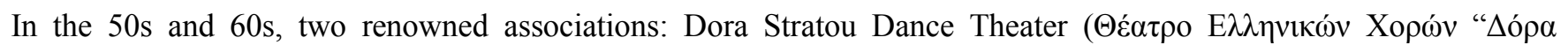

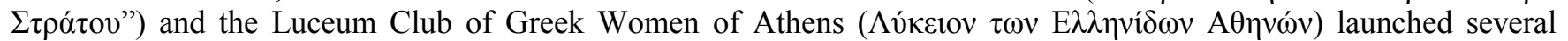
research projects throughout the countryside, with the utmost purpose of preserving and recording traditional dances and songs (Agrafioti, 1994; Antzaka \& Loutzaki, 1999). The practice of that period is still employed by many modern dance teachers, who had participated in those research projects mainly as research assistants. This is also the case of the organisers of the "En Choro" workshop Giannis Prantsidis and Mpampis Moutselos (decd.). 
Their goal was to chronicle and record the true form of dance, as it was performed amongst the elderly locals, in order to promote the authenticity of the dance through the material collected in the local communities (Loutzaki, 2010a).

From the 70s until today, despite the changes over this period of time, the organisers kept looking for authentic dance forms through short yet frequent visits to villages. The purpose of these visits was to collect new material or to substantiate and enrich their own previously collected material with new evidence, as well as to look for instructors that have carried out local researches and recorded the local repertoire, in order to recruit them as teaching personnel of the workshop. This procedure demonstrates a process for choosing the "future instructors" who will teach at the workshop and introduce "pure" material, selected for its high quality. In this context, authenticity is negated since the knowledge of the dance is transmitted through the teaching in a new context.

The purpose of these types of contact with tradition, established by the organisers of the workshop was to preserve the various dance forms and the accompanying elements. This perception has been widely dominating since the beginning of the 50s and is still prevalent today (Antzaka \& Loutzaki, 1999). According to Loutzaki (1999) and Meraklis (2004), the phenomenon of the preservation and dissemination of traditional dance is connected to the massive resettlement of the rural population to the urban centres during the 60s and the creation of cultural associations that still work as new meeting points for dancers.

Cutting the Greek traditional dance off the village square and transitioning it into a new place of a closed teaching space, such as a hotel hall for example, brings changes to its character, since it is being converted into a teaching material, and thus becomes deprived of its ritualistic nature as well as other important functions. It is now being mostly presented as a movement. For some authors, the new place is considered to be a "space" of self-referentiality, a term used by Augé (1999). In this space participants recognise themselves and their connection with dance, the co-dancers, and the history of the workshop. For those participants, who do not have the sense of relational or historical element, as well as a sense of identity, as highlighted by Augé (1999), the workshop is a "non-place".

A different view is prevalent amongst other researchers, who consider that the transition of the Greek traditional dance from its natural "habitat" to a "non-place" is connected to the corruption of the traditional dance identity, as well as material and economic dimension of the events organization process (Gyftoulas, 2003; Rompou-Levidi, 2004; Zervas, 2009), the "structural changes in the dance performance" related to teaching, performance, and festivities (Antzaka \& Loutzaki, 1999; Avdikos, 2004, 2009; Charmanta, 2004; Filippou et al. 2009; Floraki. 2010; Loutzaki, 1999, 2010b; Papakostas, 2001; Sermpezis, 2004).

Under these new circumstances, according to which we have adopted the term "non-place", there is a constant search for a new "authentic" dance repertoire, which is transmitted to the participants, so they can use it in their own "nonplaces". This way, the dance material initiates its own journey: it gets transmitted from person to person in teaching spaces, it moves to the theatre stages, it is being performed in stadiums and on squares. The organisers have made it clear that the participants should cross-check the information they receive during the workshop, by watching the dance performances within its natural "habitat". However, only a few have actually visited local communities in order to document dance material. Dance, within the context of the workshop, is presented as material being taught through different (scientific or non-scientific) teaching practices within new "non-places". At the same time, the process of traditional dance teaching becomes standardised, since it is subjected to specific rules and is performed by participants with diversity of identities, and thus deprived of its spontaneity which is observed amongst the locals during its performance within the context of the community. Therefore, given the fact that the dance is transmitted from its original location, how can the dance be "authentic" and "true" after every "journey" it takes with each teacher?

The transmission of the style is not achieved through creative interaction between community and dance, but only through the instructor, who, in turn, represents the one and only model for the participants: either from his or her research, or through a small sample of the locals, who present a limited image of the style of a specific region. Thus, we can observe a downscaling of the local stylistic diversity, since only one person, not the whole community, becomes the model of the authentic dance.

The same dynamics are equally present during the teaching of traditional songs and presentation of the costumes. Although the organisers and some instructors have knowledge of traditional music and songs, however, due to the limited time during the dance teaching, it is usually impossible to put enough emphasis on singing. The quality of song performance during the workshop can be described as poor, not only because of the limited time, but also because it is difficult for non-experts to teach singing, due to its complex nature. Furthermore, although an introduction of the costumes (presentation, way of dressing, etc.) is a positive element of the workshop development, it is not always achieved due to the lack of practical knowledge and skills on behalf of the instructors (see figures 7 and 8 ). 


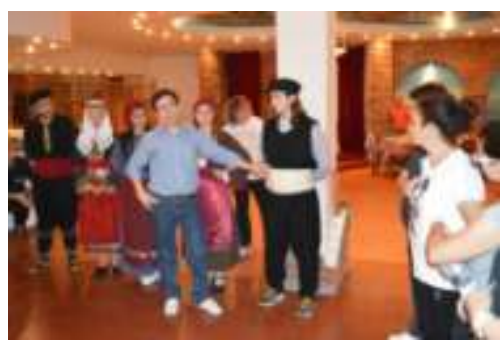

Figure 7: Assiros and Neochorouda (2013)

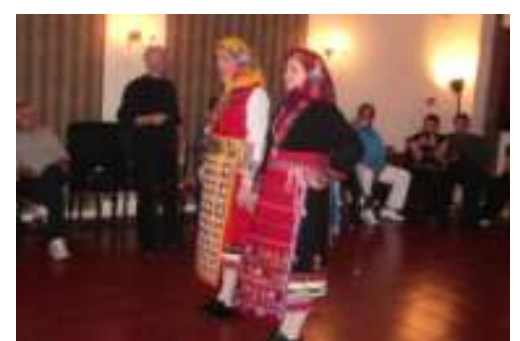

Figure 8: West Thrace (2011)

Some of the practices applied during the workshop include: inviting locals to wear traditional costumes, presenting the process of dressing into the traditional costume in its relation to the dance material, as well as costume exhibition within the workshop space (with the use of mannequins).

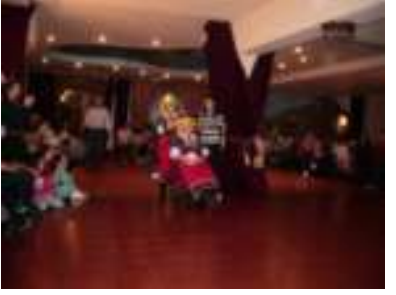

Figure 8: Aiani (Kozani) (2011)

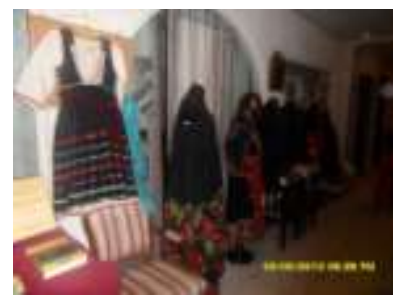

Figure 9: Costume exhibition (2013)

The organisers are aware of the challenges that arise due to the limited time of the workshop, and therefore, in order to fill the gaps within the songs and costume presentation, they adopt a practice of inviting local dancers, who represent local style of the community by demonstrating their traditional costumes. During this type of performance, participants either dance in a second (outer) circle imitating the dance of the locals and humming the lyrics, or they remain seated while they watch the locals dancing and singing (see figure 10).

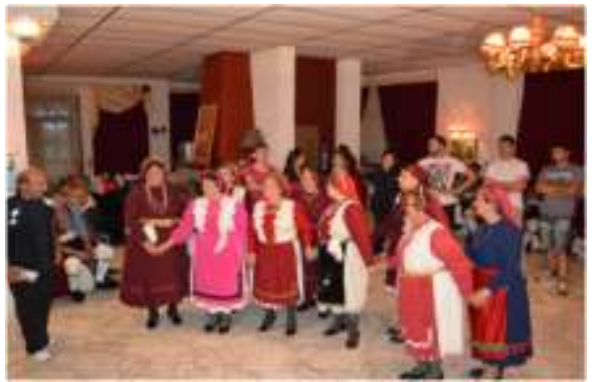

Figure 10: Asprokklisia (Trikala) (2013)

This allows participants to experience at least a small part of the local tradition, which seems to be sufficient for some as teaching and performance material. Therefore, it is possible to fragmentarily extract a small sample of information about dance and song out of a big pool of a local community dance repertoire. This small sample is sufficient to create lecture material for a dance show or to trigger further discussion.

The workshop is a yearly meeting point for many persons, who gather to dance together, sing, learn, teach, exchange views, and experience a feeling of belonging to the great dancing family of "En Choro". However, despite the participants' belief that the workshop achieves an "authentic" transmission of Greek traditional dance and its functions through an interaction in the participation space in comparison with other workshops, we can observe a creation of a new context. It delivers to both organisers and participants traditional dance, condensed in a "knowledge can" a mix of kinetic, optical, and verbal information.

The workshop of the cultural association "En Choro" can be classified as a modern expression of tradition, where the "authentic primary material is transmitted through a different experience" (Koutsouba, 2010b), and not just through a passive transfer of the "legacy of the past into the present" (Chatzitaki-Kapsomenou, 2003). Therefore, it represents an "innovative past as reconstruction of memory" (Kavouras, 2010), as well as a place of nostalgy, feelings, and desires (Theodoridis, 2015; Lofgren 1999 in Tweit 2007). Although the main goal of the workshop is preservation of the Greek popular cultural and traditional legacy, "the aim cannot be an authenticity [of a dance] in itself, as they often claim" (Liavas, 2013), since the traditional dance as an immaterial product in converted into a manageable product, by creating new dance forms during night festivities and teacher-centred teaching methods. Moreover, while facilitating access to traditional Greek dance for the general public, the media recordings (video, audio and photographic material), also contribute to the standardisation of the material, thus affecting the aesthetic image of the dance form. 
Lastly, in the words of Kiourtsakis (2003), tradition is "the rather crystalised form of an older collective creation and contains the concepts of team spirit, innovation, and its constant present" in all its contemporary aspects (p. 23). However, the workshop, being itself a modern expression of the tradition, counteracts the above statement of Kiourtsakis, since, through teaching, the dance tradition is transmitted collectively into a constantly renovated new dance context of the workshop, firmly holding on to the transmission of the "authentic" form in the constantly changing present (Niora, 2017, 2018).

[1]. Extract from the information brochure of the 4th workshop that took place in Sidirokastro between the 24th and the 29th April 1995.

\section{References}

Agrafioti, K. (1994). Everything about dance. The life of Dora Stratou. Athens: "Dora Stratou" Dance Theatre.

Antzaka-Vei E., and Loutzaki I. (1999). Dance in Greece. In Educational Greek Encyclopedia. Special issue: Theatre, Cinema, Music, Dance (Vol. 28, pp. 327-341). Athens: Ekdotike Athenon.

Augé, M. (1999). An anthropology for contemporaneous worlds. (D. Serafeidou, Trans.). Athens: Alexandria Publications.

Avdikos, E. (2004). "Fairs and dance clubs: living and reviving of the tradition". In E. Avdikos (Ed.), Choreytika Eteroklita, Lykeio Ellinidon Dramas, (pp. 203-212). Athens: Ellinika Grammata.

Avdikos, E. (2009). Introduction to the studies of popular culture. Ethnographies, popular cultures and identities. Athens: Kritiki Publishing.

Bendix, R. (1997a). In Search of Authenticity: The Formation of Folklore Studies. Madison: University of Wisconsin Press.

Bendix, R. (1997b). Authenticity. In T. A. Green (Ed.) Folklore: An encyclopedia of beliefs, customs, tales, music, and art, (pp. 72-75). Santa Barbara, California.

Buckland, T. (Ed.). (1999). Dance in the field: Theory, methods and issues in dance ethnography. London: Macmillan Press.

Charmanta, N. (2004). Transition of the dance from the square into the class and the show: thoughts, views and suggestions. In E. Avdikos (Ed.), Choreytika Eteroklita, Lykeio Ellinidon Dramas, (pp. 227-240). Athens: Ellinika Grammata.

Chatzitaki-Kapsomenou, C. (2003). Cultural associations and tradition: the issue of authenticity. In The Present of the Past. History, Ethnography, Social Anthropology, (pp. 369-382). Athens: Moraitis Foundation.

Deltsou, E. (2003). The "cultural legacy" in the present and the past: perceptions and practices of a national past and a European future. In The present of the past. History, ethnography, social anthropology, (pp. 209-231). Athens: Moraitis Foundation.

Demas, I. (2004). Music and dance folk tradition: Greek students' dance habits. (2nd ed.). Athens: ArtWork.

Felföldi, L. (2002). Authenticity and Culture. In L. Felföldi, \& T. J. Buckland, (Eds.), Authenticity, Whose Tradition? (pp. 110-119). Budapest: European Folklore Institute.

Filippou , F., Goulimaris, D., Serbezis, V., Pitsi, A., \& Genti, M. (2009). The role of dance associations in the evolution of Greek music - dance tradition: The example of "Sygathistos" dance in Velvedo of Kozani. Inquiries in Sport \& Physical Education, 7(1), 30-38.

Filippou, F. (1999). The Greek popular dance and its relation with the dance associations. Proceedings of the 1st Panhellenic Congress on Folk Culture. The intertemporal evolution of traditional dance in Greece (pp. 57-59).

Floraki, L. (2010). Popular culture, folkloric representation. In P. Kavouras (Ed.), Folklore and Tradition. Issues of representations and performance of music and dance, (pp. 103-112). Athens: Nissos Publications.

Formozis, P. (1932). The work and effort of Arg. N. Andreopoulos for the recording of Greek dances and songs. Ethnography (Laografia) Bulletin of the Greek Ethnographic Society, 1(3-4), 503-513.

Giurchescu, A. and Torp, L. (1991). Theory and methods in dance research: A European approach to the holistic study of dance. Yearbook for Traditional music, 23, 1-10.

Gyftoulas, N. (2003). Dance act and social behaviour in the neohellenic cultural field. In Arts II: Review of Greek Music and Dance. Volume E. Greek dance act. Traditional and contemporary dance (pp. 223-229). Athens: Hellenic Open University.

Hanna, J. L. (1987). To dance is human: A theory of non-verbal communication (2nd ed.). Austin: University of Texas Press.

Hoerburger, F. (1968). Once again: on the concept of 'folk dance.' Journal of the International Folk Music Council 20, 30-32. doi: 10.1080/14647893.2011.554976 
Kaschl, E. (2003). Dance and authenticity in Israel and Palestine: performing the nation. Leiden: Brill.

Kavouras, P. (2010). Folklore and Tradition: Aspects and Transformations of a Modernist Ideological Conception. In P. Kavouras (Ed.), Folklore and Traditions: Issues of re-production and performance of music and dance (pp. 29-86). Athens: Nissos Publications.

Keali' inohomokou, W. J. (1972). Folk Dance. In R. Dorson (Ed.), Folklore and folklife. An introduction (pp. 381- 404). Chicago: University of Chicago Press.

Kiourtsakis, G. (2003). The problem of the tradition. Athens: Nefeli Publishing

Koutsouba, M. (1991). Greek dance groups of Plaka: A case of 'airport' art (Master's thesis). University of Surrey, UK.

Koutsouba, M. (1997). Plurality in motion: Dance and cultural identity on the Greek Ionian Island of Lefkada (Doctoral dissertation). Goldsmith College, University of London, UK.

Koutsouba, M. (1999). 'Outsider' in an ' inside' world, or dance ethnography at home. In T. J. Buckland (Ed.), Dance in the field: theory, methods, and issues in dance ethnography (pp. 186-195). New York: St. Martin's Press.

Koutsouba, M. (2010a). The teaching of Greek traditional dance in the contemporary educational context. In I. Demas, V. Tyrovola, \& M. Koutsouba (Eds.), Greek traditional dance. Theorisations for its discourse, writing and teaching (pp. 101-126). Athens: self-published.

Koutsouba, M. (2010b). The Greek traditional dance at its "first" and "second" existence. Views and concerns. Paper presented at the 18th World Conference of Physical Education and Sports. Komotini, Greece. Retrieved from http://www.phyed.duth.gr/undergraduate/images/files/congress/2010/oral10/Dance.pdf

Koutsouba, M. (2012). Re-thinking and re-interpreting the past: historical course and issues of identity of the teaching of Greek folk dance to the physical education teachers from 1909 till 1983. Kinesiologia, 1, 32-39. Retrieved from http://kinisiologia.phed.uoa.gr/fileadmin/kinisiologia.phed.uoa.gr/uploads/KOUTSOUBA.pdf

Kyriakidou-Nestoros, A. (2008). The romantic concept of the nation and Ehnography. In K. Gkotsis \& E. SpathariBegliti (Eds.), Collection of Essays on Public and Private Life in Greece (19 ${ }^{\text {th }}-20^{\text {th }}$ century), (pp. 25-40). Patra: Hellenic Open University Editions.

Lalioti, V. (2010). Tradition, performance and folklore. The ethnographic example of the song ghana in Malta. In P. Kavouras (Ed.), Folklore and traditions. Issues of re-production and performance of music and dance, (pp. 131-139). Athens: Nissos Publications.

Lange, R. (1980). The development of anthropological dance research. Dance Studies, 4, 1-36.

Lange, R. (1984). Guidelines for fieldwork on traditional dance methods and checklist. Dance Studies, 8, 7-48.

Liavas, L. (2013). From the river of tradition to the folklore. To Vima. Retrieved from http://www.tovima.gr/opinions/article/?aid=526548

Loutzaki, I. (1999). The Association as milieu for dance activity. In Music of Thrace. An interdisciplinary approach. Evros, (pp. 193-247). Athens: The Friends of Music-Research Programme 'Thrace'.

Loutzaki I. (2010a). Greek dance - Local traditions and their representations. In Dance Anthropology. Five essays, (pp. 77-134). Athens: Faculty Music Studies. University of Athens.

Loutzaki, I. (2010b). Lykeio Ellinidon. From "Big National Celebrations" to performance shows with artistic pretensions. In P. Kavouras (Ed.), Folklore and Tradition. Issues of re-presentation and performance of music and dance, (pp. 113-130). Athens: Nissos Publications.

Meraklis, G. M. (1972). What folklorismus is. Ethnography (Laografia), Bulletin of the Greek Ethnographic Society, 28, 27-38.

Meraklis, G. M. (2001). Neohellenic popular life. Views and aspects. Athens: Livanis Publishing Organisation.

Meraklis, G. M. (2004). Ethnographic issues. Athens: Kastaniotis Editions and Diatton Publishing

Morrison, C. (2003). Culture at the core: Invented Traditions and Imagined Communities. Part I: Identity Formation. International Review of Scottish Studies, 28, 3-21.

Mpada, K. (2011). From the study of the material aspect of life and culture to the study of the overall culture of everyday life. In Educational Material on the Undergraduate Programme: Studies in Hellenic Culture. Open University of Cyprus, Thematic Unit ELP 10. Retrieved from http://users.uoi.gr/gramisar/prosopiko/bada/Bada_Panepistimio_Kiprou.pdf

Nahachewsky, A. (1995). Participatory and presentational dance as ethnochoreological categories. Dance Research Journal, 27(1), 1-15.

Nahachewsky, A. (2001). Once again: on the concept of 'second existence folk dance'. International Council for Traditional Music, 33, 17-28.

Niora, N. (2017). Learning and administration of Greek traditional dance. The case of a timeless seminar in Greece. (Doctoral dissertation). DPESS, University of Athens, Athens. 
Niora, N. (2018). 'Authentic' dances, 'expert-authorities' and 'authentic' mouthpieces of the local traditions in the Greek traditional dance workshops. Chorevo magazine, 2(3), 42-45.

Papakostas. C. (2001). Dance from the community onto the stage: techniques and controversies. Proceedings of the 2nd Hellenic Conference on Folk Culture "Melody, Speece, Movement". Serres: TEFAA Serron.

Papapavlou, M. (2010). Folklore and folklorism. Convergences and divergences. In P. Kavouras, (Ed.), Folklore and Tradition. Issues of re-presentation and performance of music and dance, (pp. 89-102). Athens: Nissos Publications.

Politis, G. N. (1920). Laografika symmeikta, Publications of the Ethnographic Archive of the Hellenic Folklore Research Center, 2, 274. Athens: Paraskevas Leonis Printing Company.

Rompou-Levidi, M. (2004). Dance: from the myth to the representation. In E. Avdikos (Ed.), Choreytika Eteroklita, Lykeio Ellinidon Dramas, (pp. 163-182). Athens: Ellinika Grammata.

Sermpezis V. (2004). Tradition-performance on scene: popular creation or eponymous process? In E. Avdikos (Ed.), Choreytika Eteroklita, Lykeio Ellinidon Dramas, (pp. 281-290). Athens: Ellinika Grammata.

Shay, A. (1999). Parallel traditions: state folk dance ensembles and folk dance in 'The Field'. Dance Research Journal, 31(1), 29-56.

Shay, A. (2002). Choreographic Politics: State Folk Dance Companies, Representation and Power. Middletown: Wesleyan University Press.

Theodoridis, P. (2015). From Utopia to Nostalgia and other small essays. Thessaloniki: To Vivlio.

Tweit, E. M. (2007). Folklore on display: The authenticity debate revisited. Studia ethnologica Croatica, 19, 293-302.

Tyrovola, V. (2008). Influences and cultural crosses in the dance tradition between Greece and the Balkans. The case of the 'Hasapiko dance'. Studia Choreologica, 10, 53-95.

Tyrovola, V., Karepidis I., \& Kardaris, D. (2007). Pontian dances. Past and present. Structural-morphologic and typological approach. Searches at Physical Education and Sports Science, 5, 1-24.

Zervas, Y. 2009. Pedagogical and psychological values of tradition. Proceedings of the $14^{\text {th }}$ Pan-Hellenic Congress of Lyceum Club of Greek Women, 79-84. 